\title{
Conexiones revolucionarias: repercusiones de la expropiación petrolera mexicana en Bolivia, 1938
}

\begin{abstract}
This article deals with a relevant subject in Latin American historiography, that being the Mexican oil expropriation during the Lázaro Cárdenas government and provides original information as well as an innovative approach that goes beyond strictly national historiographies, with the intention of contributing both to Bolivian and Mexican history. The Mexican expropriation of 1938 reached a transnational dimension beyond its diplomatic implications; an experience perceived through quite different prisms in each Latin American country. How was the Mexican expropriation viewed in the Bolivian Andes? We have argued that in La Paz and Sucre, various sectors of the society read that expropriation through the filters of the conflict with Standard Oil of Bolivia and of the ideological and political debate surrounding the recently created YFPB. This nationalistic episode was charged with another meaning in adopting it to a Bolivian context, by simultaneously being in dialogue with the previous substratum of the reception to the Mexican revolution in the region, together with the particular Andean political, economic and diplomatic context. Reasons of national and international order explain the reactions in Bolivia when faced with the Mexican petroleum episode, as well as the perception of those reactions by the Mexican diplomatic corps.
\end{abstract}




\section{Keywords}

Mexican and Bolivian diplomacy, Mexican oil expropriation, petroleum, revolutionary networks, YPFB (Yacimientos Petrolíferos Fiscales Bolivianos)

\section{Resumen}

Este trabajo trata un tema relevante en la historiografía latinoamericana como es la expropiación petrolera mexicana durante el gobierno de Lázaro Cárdenas y aporta información original así como un enfoque innovador que desborda las historiografías estrictamente nacionales, intentando contribuir tanto a la historia de Bolivia como a la mexicana. La expropiación mexicana de 1938 alcanzó una dimensión trasnacional más allá de sus repercusiones diplomáticas: una experiencia percibida bajo muy diversos prismas en cada país latinoamericano. ¿Cómo fue vista la expropiación mexicana en los Andes bolivianos? Se argumenta que en la Paz, y en Sucre, diversos sectores de la sociedad leyeron esa expropiación tras los filtros del conflicto con la Standard Oil of Bolivia y del debate ideológico y político en torno a la recién creada YPFB, y cargaron de otro significado este episodio nacionalista al adaptarlo al contexto boliviano, dialogando simultáneamente con el sustrato previo de recepción de la revolución mexicana en la región, así como con el especial contexto político, económico y diplomático andino. Razones de orden nacional e internacional explican las reacciones ante el episodio petrolero mexicano en Bolivia, tanto como la percepción de estas por parte de la diplomacia mexicana.

\section{Palabras claves}

diplomacia mexicana y boliviana, expropiación petrolera mexicana, interconexiones revolucionarias, petróleo, YPFB (Yacimientos Petroliferos Fiscales de Bolivia)

"Bolivia ha ingresado en un régimen de socialismo de Estado, y su idea es estudiar detenidamente el proceso y la técnica usada por los gobiernos mexicanos revolucionarios, que han logrado la transformación de México", declaró en julio de 1937 -empleando clara retórica propagandística, dirigida simultáneamente a las audiencias mexicana y boliviana- el ministro de la Legación de Bolivia en México, Alfredo Sanjinés. ${ }^{1}$ Estas declaraciones se

\footnotetext{
${ }^{1}$ Acervo Histórico Diplomático, de la Secretaría de Relaciones Exteriores (México), en adelante AHSRE; III-89-4, 9 de julio de 1937, Alfredo Sanjinés al Secretario de Relaciones Exteriores, General Eduardo Hay, México.
} 
orientaban a respaldar la aproximación que acontecía a fines de la década de 1930, en la posguerra del Chaco, entre los gobiernos de Bolivia y México, acercamiento efímero aunque con secuelas quizás no tan fugaces. En este artículo indagamos las interacciones que vincularon a Bolivia y México entre 1936 y 1940, enfocándonos específicamente en su componente "petrolero": el flujo de doble vía de ideas, informaciones y representaciones, acerca de las políticas petroleras y sus disyuntivas diplomáticas. ${ }^{2}$ En particular, estudiamos las repercusiones y la recepción que alcanzó, en el escenario político y la opinión pública de Bolivia, la expropiación petrolera mexicana de 18 de marzo de 1938 -cómo fue percibida, contestada y cargada de un nuevo significado, sin perder de vista, asimismo, las percepciones desarrolladas en México sobre la vida política y el problema petrolífero boliviano.

El contexto actual confiere renovado interés a la historia de la economía política de las industrias extractivas. Científicos de muy diversas disciplinas han venido estudiando, con diferentes enfoques, el auge de la minería y de la industria de hidrocarburos - petróleo, gas y otros combustibles- que despuntan en Latinoamérica a partir de la década de 1990. Al examinar las distintas vías por las cuales la explotación de los recursos del subsuelo impulsa transformaciones profundas en la economía, la sociedad, la vida política, la gobernanza y el medio ambiente, los estudiosos han tornado a observar sus antecedentes históricos (Orihuela y Thorp), analizando las oleadas de privatización y nacionalización, y subrayando cómo cada oleada de expansión de estas industrias alcanzó impacto político y económico local y nacional tanto como transnacional (Bebbington; Berrios, Marak \& Morgenstern; Gavaldà Palacín). Los debates actuales en la región andina (Bolivia, Colombia, Ecuador, Perú) en torno a la formulación de un marco institucional y de políticas públicas adecuado a la explotación de hidrocarburos -que conjugue tanto los intereses del Estado como extractor y redistribuidor de rentas, del capital trasnacional, de la sociedad, y la protección del medio ambiente- coinciden hoy con las controversias sobre los contenidos y los alcances de una reforma energética en México que significaría un viraje con respecto a ocho décadas de historia petrolera continua (Meyer 2014, 1). Por su parte, las preocupaciones de políticos y científicos en torno a los procesos de integración energética en América y su

\footnotetext{
${ }^{2}$ Visiones panorámicas de los tratos y vinculaciones entre México y Bolivia, en Ruiz Guerra y Palacios.
} 
dinámica transnacional contribuyen también a colocar las cuestiones energéticas en el centro de la atención política. ${ }^{3}$

A la luz de los interrogantes actuales, este trabajo, sustentado en una investigación histórica documentada, plantea que la dinámica transnacional característica de los asuntos petroleros y gasíferos del presente encuentra también vislumbres en el pasado: en marzo-julio de 1938, la nacionalización petrolera mexicana desbordó la repercusión del conflicto diplomático con las compañías petroleras y las potencias, y alcanzó resonancias transnacionales, siendo percibida de muy diversa forma por los gobiernos y opinión pública de los países latinoamericanos. ${ }^{4}$ El ambiente boliviano era especialmente sensible a los asuntos de la minería y el petróleo: un año antes, el gobierno había afectado, por sorpresa, las propiedades de la Standard Oil of Bolivia, al disponer la caducidad de sus concesiones.

Uno de los resultados de la expropiación mexicana fue la eclosión de un ciclo de controversias conceptuales, ideológicas y políticas, empresariales, gubernamentales y diplomáticas, en América y Europa, en relación a las garantías a la propiedad y derechos de explotación de los recursos del subsuelo, la inversión extranjera, el Estado, la propiedad y el empleo (Rodman 110-120; Maurer 260-296). En este debate trasnacional fueron vinculados, sin que mexicanos o bolivianos lo hubieran planeado o buscado desde un primer momento, ambos episodios nacionalistas: la expropiación mexicana y la incautación boliviana de 1937. En consecuencia, nos interesa examinar las conexiones recíprocas entre ambos acontecimientos, centrándonos en la recepción que tuvo en Bolivia el episodio petrolero mexicano del año $1938 .^{5}$ Nos parece que ello brinda elementos para conocer mejor la recepción de la cuestión petrolera mexicana en otro país con grandes recursos minerales y energéticos como es Bolivia, donde se habían adoptado también medidas nacionalistas. Se arroja luz también sobre los alcances y significados de la historia de las relaciones boliviano-mexicanas antes de la Segunda Guerra

\footnotetext{
${ }^{3}$ Véanse los trabajos de Rousseau, Osorio Romero, Gudynas, y Carrizo \& Ramousse, citados al final.

${ }^{4}$ Tal como se ha mostrado y documentado en Kiddle y Zuleta 2013.

${ }^{5}$ Este examen se funda en un relevamiento de prensa y fuentes diplomáticas, AHSRE, y del Archivo Histórico de la Cancillería, Ministerio de Relaciones Exteriores (Estado Plurinacional de Bolivia), en adelante AHMREB. Se ha revisado artículos periodísticos publicados en la prensa de mayor circulación de las ciudades de La Paz y Sucre, y algunas publicaciones de Cochabamba y de Santa Cruz, entre 1937 y 1938, tanto en el Archivo y Bibliotecas Nacionales de Bolivia (Sucre) como en acervos hemerográficos de La Paz (Biblioteca Municipal y Hemeroteca de la Universidad de San Andrés). Agradezco al personal de estos acervos su disposición y generosa atención, y en particular, la hospitalidad y cobijo de los colegas del Archivo de la Cancillería, en La Paz, así como del Archivo y Biblioteca Nacionales de Bolivia, Sucre.
} 
Mundial, tema relevante, ya que las interacciones fluidas entre ambas naciones fueron retomadas poco más de una década después, cuando en otro contexto muy diferente, en el marco de la Guerra Fría, se desarrolló en Bolivia un profundo ciclo revolucionario social, agrario y minero impulsado por los gobiernos del MNR (Langer 67-88). ${ }^{6}$

\section{Tramas petroleras}

El nacionalismo petrolero no era para nada ajeno al escenario boliviano de los años 1930: la afirmación de los derechos del Estado sobre los recursos petrolíferos se remontaba a comienzos de la década del veinte (1921), y la preocupación por el control estatal sobre el subsuelo se había exacerbado como consecuencia de la Guerra del Chaco (1932-1935). Al lado de la minería del estaño, que colocaba a Bolivia como uno de los principales exportadores de minerales del mundo, la industria petrolera boliviana era incipiente a mediados de los años treinta, y de magnitud muy reducida comparada con la mexicana (United States Tariff Commission 158). La principal compañía petrolera era la estadounidense Standard Oil (of Bolivia). ${ }^{7}$ La producción de esta compañía estaba a la baja desde hacía un lustro (Maurer 294-295, fig. 7.7) y había suscitado varias controversias por supuestos incumplimientos a los términos de su concesión. Después de algunas acusaciones y denuncias, que incluso motivaron una investigación del Congreso y de la compañía estatal YPF argentina (Klein 55-59), el coronel David Toro, presidente de una junta cívico-militar auto proclamada socialista, dispuso el 13 de marzo de 1937 la caducidad de las concesiones de la Standard y, posteriormente el 17 de ese mes, la incautación de sus bienes (Valdivieso y Salamanca 16).

\footnotetext{
${ }^{6}$ Véase un botón de muestra en estos títulos: "Primer reparto de tierras en Bolivia. Aportación de la Confederación Nacional Campesina", El Nacional, México, 31 de julio de 1953; "Asesoró a Bolivia un mexicano en materia agraria", Excélsior, México, 5 de agosto de 1953; "La Reforma Agraria de Bolivia. Antecedentes, fundamentaciones y metas", por Lucio Mendieta y Núñez, 27 de abril de 1954; "Bolivia, al igual que México, reparte los latifundios a los campesinos", Excélsior, México, 4 de marzo de 1957; "Misión en Bolivia (PEMEX), El financiamiento de la primera aventura formal", 3 de octubre de 1960; en colección: Recortes de Prensa, Archivos Económicos Hemerográficos (en adelante AEH) Biblioteca Miguel Lerdo de Tejada (México). En la formación de esta colección intervino Tristan Marof, durante su exilio en México en los tempranos años treinta (ver Marof).

${ }^{7}$ Esta compañía era filial de la Standard Oil of New Jersey. Se respeta aquí el uso empleado en los folletos publicados por la compañía, en los que aparece como Standard Oil of Bolivia, nombre con el cual se registró en La Paz, desde el año de 1922, aunque sus oficinas y gerencia se encontraban en la ciudad de Buenos Aires.
} 
En un principio, este acontecimiento no alcanzó gran repercusión pública en México, aunque sí en los países vecinos a Bolivia, por varias razones, entre ellas, el lento avance de las negociaciones de paz con el Paraguay. La opinión pública mexicana no recibió, en ese momento, más que pálidos reflejos de las noticias en la prensa. ${ }^{8}$ Un año después, cuando el presidente Lázaro Cárdenas expropió las compañías petroleras y se rompieron relaciones diplomáticas con Gran Bretaña, el caso boliviano adquiriría otra relevancia. Aunque, como se verá más abajo, desde temprano el gobierno mexicano se había mantenido atento a través de canales diplomáticos a la problemática petrolera boliviana, y a sus alcances geopolíticos.

En México -mientras Bolivia enfrentaba los desafíos de la posguerra y era gobernada por militares de la llamada "generación del Chaco" que propugnaban la reforma del orden político y económico liberal exportador en agonía desde $1929^{9}$ - los caminos de la revolución mexicana iniciada en 1910 alcanzaron su máxima expresión, con el gobierno de Lázaro Cárdenas (19341940). Cárdenas impulsó un conjunto de reformas políticas, económicas y sociales de considerable impronta como la conocida reforma agraria. ${ }^{10}$ Precisamente en 1937, después de décadas de conflictos (desde 1917), la controversia con las compañías petroleras extranjeras por el control de los hidrocarburos y de los recursos fiscales que generaban su explotación y exportación -junto a su cuestionable manejo del ambiente, de los recursos naturales y de la mano de obra- alcanzó su punto más álgido. Agravada la tensión por razón de un conflicto laboral cuya resolución quedó estancada, el presidente respondió el 18 de marzo de 1938 al decretar la expropiación de 17 compañías extranjeras, nacionalizando no sólo el petróleo (bajo dominio de la Nación desde la sanción de la Constitución de 1917) sino además su industrialización, comercialización y exportación, y creando a continuación un monopolio estatal. ${ }^{11}$

\footnotetext{
8 “La Standard Oil expulsada de Bolivia” El Universal, México D.F., 17 de marzo de 1937.

9 H. Klein considera el periodo 1936-1939 como de "socialismo militar". Para consultar una postura revisionista, ver Ferrán Gallego y Carlos Roy Aramayo. Consideramos que los gobiernos militares emergidos de la crisis posterior al Chaco representaban la caducidad del viejo orden liberal, y abrieron paso a un periodo de efervescencia política profunda, contemplando reformas sociales y económicas importantes, si bien, no plenamente revolucionarias.

${ }^{10}$ Para una síntesis general, véase Marván Laborde. Para otras visiones complementarias ver "La Revolución Mexicana, distintas perspectivas", Historia Mexicana, LX (2): 238, octubre-diciembre 2010.

${ }^{11}$ Con la expropiación, Cárdenas consolidó el reposicionamiento diplomático del país bajo el signo del antifascismo, afirmando con ello, simultáneamente, un conjunto de reformas políticas, económicas y sociales. En la historiografía se discute el significado político y económico de la coyuntura expropiatoria
} 
Sostenida por instituciones gubernamentales, así como organizaciones políticas y sociales encuadradas en el aparato cardenista, y respaldada por un amplio movimiento de adhesión popular, la expropiación afirmó nociones identitarias fundantes de la nacionalidad mexicana de la posrevolución, de las cuales la historiografía no ha podido desprenderse del todo. ${ }^{12}$ Por esta razón, se afianzó la identificación de la nacionalidad con la defensa del petróleo, de la expropiación como una verdadera gesta de independencia económica nacional y de unidad, y del petróleo mismo como símbolo de la riqueza de la Nación, puesto que se consideraba que la medida expropiatoria consolidaba la recuperación del interés nacional mexicano después de una historia de siglos de subordinación colonial e imperialista (Pérez Monfort 273-289). Igualmente, se forjaron nuevas tradiciones, por ejemplo, la celebración del 18 de Marzo (día de la expropiación) como una efeméride nacional que simboliza la independencia y soberanía.

La expropiación mexicana alimentó campañas propagandísticas tanto en México como en el exterior, instrumentadas tanto por las compañías expropiadas, como por el propio gobierno mexicano a través de sus agencias, junto con un grupo de variados actores individuales y colectivos (partidos políticos, sindicatos, asociaciones culturales, organizaciones empresariales). ${ }^{13}$ A diferencia de la incautación a las propiedades de la Standard Oil en Bolivia, cuyas repercusiones se concentraron en un primer momento en los círculos de negocios y diplomáticos estadounidenses, y dentro del ámbito del Cono Sur y los Andes, el episodio mexicano irradió en América y en Europa: atrajo la atención de los gobiernos de la región, y concentró miradas en la política del Buen Vecino, en un momento de tormentas políticas en Occidente, justo cuando el fascismo se robustecía en Europa. ${ }^{14}$ Para Shell y Standard Oil, las más grandes de las compañías despojadas, después de la experiencia boliviana, la cuestión era de principios: debido a la oferta venezolana, el asunto petrolero mexicano no tenía tanta importancia económica, pero sí potencial simbólico (Schuler 70).

\footnotetext{
en la dinámica política interna del llamado "cardenismo", al que siguió una etapa de progresiva moderación política en contraste con sus cuatro años anteriores. Al respecto, véase la bibliografía al final.

${ }^{12}$ Véase Philip 209-272 y la excelente revisión de la historiografía sobre el tema de Bucheli 339-362.

${ }^{13}$ Véanse los trabajos de Huesca y Gojman de Backal. Schuler 91-151 presenta un análisis desmitificador de la economía política y diplomacia de la expropiación.

${ }^{14}$ Rodman, 107-125, examina detenidamente los contrastes y diferentes consecuencias entre la afectación a la Standard por el gobierno boliviano y la expropiación petrolera mexicana.
} 
Finalmente, la actitud resuelta del gobierno de Cárdenas provocó la interrupción de relaciones entre México y Gran Bretaña durante los años 1938-1942, hecho que concitó la sorpresa de sus vecinos latinoamericanos, por considerarla una muestra de autonomía internacional. Mientras unos observadores latinoamericanos fueron críticos a la medida, otros subrayaron sus cualidades, e incluso algunos manifestaron enfáticas adhesiones antiimperialistas (Kiddle y Zuleta). Un factor de peso en estas repercusiones fue la definición internacional por la defensa de principios progresistas adoptada por el gobierno de Cárdenas, que colocó al país (sin restablecer todavía relaciones con la URSS) en el ala izquierda de las posiciones democráticas en el ámbito internacional y en el multilateral. Esta estrategia, dirigida simultáneamente a legitimar la experiencia política mexicana ante los observadores internacionales y al mismo tiempo a robustecer la aceptación de grupos izquierdistas y progresistas del escenario doméstico y su apoyo para proponer la emulación del modelo mexicano de revolución -en particular el movimiento obrero y campesino organizado- cosechó tanto adhesiones y amistades como cuestionamientos y detractores en la América del Sur. ${ }^{15}$ Bolivia era por entonces terreno fértil para unos y otros, en especial en lo que concernía a asuntos agrarios, petroleros y campesinos.

\section{La mirada andina: "Siguiendo el ejemplo de Bolivia, Méjico expropia las compañías petroleras"16}

El titular de este periódico de Lima, publicado pocos días después de la expropiación mexicana, el 29 de marzo de 1938, expresaba una preocupación sin duda difícil de aprehender desde el mirador mexicano, donde la opinión pública se hallaba, en lo general, compenetrada en la idea de lo distintivo de la riqueza petrolera del país y en la percepción del nacionalismo petrolero como resultado exclusivo de la gesta revolucionaria que finalmente parecía culminar, después de enfrentar una intervención extranjera e inagotables resistencias a la nacionalización del subsuelo dispuesta por la Constitución de 1917 y puesta en marcha en la administración de Lázaro Cárdenas. ${ }^{17}$ No obstante, el titular en sí mismo es una muestra de la preocupación de las

\footnotetext{
${ }^{15}$ Véase la novedosa investigación de Kiddle 2010.

${ }^{16}$ Informaciones petrolíferas, Lima 29 marzo 1938, AHSRE, LE 683.

${ }^{17}$ Véase Meyer 2009. Acerca de los avatares de la política petrolera en la posrevolución, el izquierdista boliviano Tristan Marof señaló, a comienzos de la década de 1930: “El petróleo en México y el artículo 27: leyes mexicanas que quedaron escritas en el papel” (Marof 57-67).
} 
élites sudamericanas por precisar una genealogía entre las diferentes políticas nacionalistas respecto a la industria petrolera, independientemente de la importancia económica relativa tanto de cada industria como del alcance y magnitud de las medidas de fiscalización emprendidas por los gobiernos para aumentar el control sobre la explotación del subsuelo y los recursos por esta generados. $^{18}$

Tal como señaló el encargado de la legación mexicana en La Paz, José Maximiliano Alfonso de Rosenzweig Díaz en precisos informes, la cuestión petrolera era, junto con el estaño -el metal que movía el motor económico del país- un asunto crítico de la vida política boliviana desde la Guerra del Chaco, ya que el conflicto había puesto en tela de juicio la jurisdicción de terrenos potencialmente petrolíferos y el abastecimiento de combustibles para el desarrollo de las operaciones militares (Rout 141). ${ }^{19}$ El problema petrolero mexicano fue leído a la luz de las pugnas y conflictos causados por la tendencia a un mayor control gubernamental sobre la industria minera del estaño y del petróleo, que si bien se afirmaba ya desde la crisis de 1929, se consolidó en los años de posguerra. La expropiación mexicana alcanzó significación a la vista de los agravios y conflictos suscitados con la compañía petrolera Standard Oil of Bolivia, y en el marco del debate ideológico y político en torno al funcionamiento de la nueva empresa petrolera estatal, Yacimientos Petrolíferos Fiscales Bolivianos (YPFB), fundada bajo la influencia del modelo de la argentina Yacimientos Petrolíferos Fiscales, en 1936. A su vez, estas lecturas estuvieron determinadas por los desvelos de la etapa final de negociaciones de paz en la Conferencia de Paz del Chaco, en Buenos Aires (julio 1935-enero de 1939)..$^{20}$

De acuerdo al ministro Rosenzweig Díaz, la noticia de la expropiación mexicana produjo amplios efectos en la opinión de los bolivianos, y alcanzó importante difusión periodística, política y diplomática. El caso judicial con

\footnotetext{
${ }^{18}$ Un periódico de Buenos Aires publicó “Un proyecto de Irigoyen convertido en realidad en Méjico”. La noticia de la expropiación mexicana alcanzó amplia difusión en Bolivia, por diferentes vías, principalmente la prensa escrita, el debate político, el cabildeo diplomático, la difusión de proclamas y adhesiones de organizaciones militares, obreras y estudiantiles, e incluso, la propia Standard Oil. Prensa, 25 de marzo de 1938 (AHSRE, LE 562).

${ }^{19}$ AHSRE, 31-24-5; 30-3-15 “El petróleo y su influencia en la política sudamericana", Rosenzweig a Relaciones, Informes Políticos, 1938.

${ }^{20}$ El 21 de julio de 1938 se firmó en Buenos Aires el Tratado de Paz, Amistad y Límites entre el Paraguay y Bolivia que restablecía la paz entre ambos países.
} 
la Standard Oil of Bolivia y el reclamo de esta compañía por la satisfacción del pago de una compensación, la definición de una política petrolera doméstica e internacional y las grandes cuestiones de la política agraria, minera y educacional, se encontraban en el centro de las tormentas políticas y debates constitucionales bolivianos de ese año de 1938, especialmente desde la instalación de la Convención (junio de 1938), y determinaron el contexto de reconocimiento boliviano al momento de recepción de la noticia de la medida expropiatoria mexicana. ${ }^{21}$

La atención al contexto cronológico tanto boliviano como mexicano ilumina los procesos de recepción de las noticias acerca del petróleo mexicano y sus elementos determinantes. Cuatro días después del decreto del presidente Cárdenas, el 22 de marzo de 1938, pasado ya un año de la disposición de caducidad, y después de cabildeos en La Paz, Buenos Aires y Washington (FRUS 322), 22 la compañía Standard resolvió apelar ante la Corte Suprema de Justicia boliviana, alegando que si bien era derecho del Estado la cancelación de los contratos de concesión, no había, al contrario, respaldo legal para la decisión de su incautación (Standard Oil Company of Bolivia 12). ${ }^{23}$ Resulta llamativo que apenas el 20 de marzo de 1938 las oficinas de Nueva York dispusieran la presentación de un alegato ante la Corte Suprema en Sucre, justo dos días después de la expropiación mexicana. El 21 de marzo, cuando la prensa internacional tomaba nota de la expropiación mexicana, el secretario de Estado Cordell Hull había telegrafiado a R.G. Caldwell, su ministro en Bolivia, indicándole que tomara distancia de las quejas de la petrolera y ordenando muy claramente se abstuviera de apoyar en persona, aunque le fuera solicitado, las gestiones de la compañía petrolera ante la justicia, ni tampoco ante el ministro de relaciones exteriores boliviano (FRUS 324). ${ }^{24}$ La coincidencia entre la decisión de la Standard de acudir a la Corte

\footnotetext{
${ }^{21}$ La Convención se estableció como asamblea constituyente, cuyas agitadas sesiones produjeron incluso una crisis de gabinete (Gallego 31-100). Así mismo, se conformó por elecciones, y comenzó a sesionar precisamente el 13 de marzo de 1938, pocos días antes del decreto de expropiación.

${ }^{22}$ Parecía altamente probable que una presentación ante la justicia cerraría definitivamente todo curso de resolución. Foreign Reports of the United States, 1938, vol. V, "Informal Assistance to the Standard Oil Company of New Jersey in Connection with the Confiscation of its Properties in Bolivia"; Duggan, Memorandum, March 16, 1938: 322. En adelante la serie Foreign Reports se consigna como FRUS.

${ }^{23}$ FRUS, 1938, vol. V, "Informal Assistance to the Standard Oil Company of New Jersey in Connection with the Confiscation of its Properties in Bolivia"; Duggan, Memorandum, March 16, 1938: 323.

${ }^{24}$ Robert Granville Caldwell fungió como enviado extraordinario y ministro plenipotenciario de la Legación de los Estados Unidos en La Paz, entre 21 de agosto de 1937 y 23 de junio de 1939.
} 
Suprema de Bolivia, y la expropiación mexicana, llegó a ser entonces señalada por la misma empresa (Standard i). ${ }^{25}$

Una anécdota resulta indicativa de la insospechada conexión entre los acontecimientos bolivianos y mexicanos. Tal era la compenetración del público boliviano con la marcha de los asuntos petrolíferos, ${ }^{26}$ que cuando el 28 de julio de 1938 se trasmitió por noticieros radiales que la Corte Suprema de México había denegado el recurso de nulidad reclamado por la Compañía El Águila, de capital británico, declarándolo improcedente, se produjo una confusión: algunos periódicos de provincia y la importante radio Illimani informaron, equivocadamente, que la Corte Suprema de Bolivia, con sede en la ciudad de Sucre, había fallado contra la reclamación de la Standard Oil. El Departamento Nacional de Propaganda, desde La Paz, se apresuró a aclarar el equívoco, explicando que la noticia se refería a una decisión del Tribunal Supremo de México, no del Supremo de Bolivia, pero que "debía constituir, en todo caso, un antecedente auspicioso". ${ }^{27}$

Mientras corría el compás de espera en torno a las reclamaciones de la Standard Oil, comenzó a desplegarse una campaña en contra de YPFB, su organización, su gestión administrativa y contable, y sus proyectos de vinculación internacional con Brasil y Argentina. El ingeniero militar Dionisio Foianini, excombatiente, presidente y fundador de YPFB, y actor intelectual de la incautación petrolera boliviana, hizo declaraciones tanto en Bolivia como en Buenos Aires -donde YPFB había instalado oficinas- reconociendo la importancia de la medida mexicana y del valor del presidente Lázaro Cárdenas en la lucha contra las compañías petroleras y en pos de la soberanía económica de las naciones americanas, refiriéndose a la medida como la "segunda independencia". ${ }^{28}$ Si por entonces era frecuente el enjuiciamiento a YPFB en Bolivia por los partidarios de un arreglo favorable a la Standard,

\footnotetext{
25 "The Bolivian seizure was the 1937 prelude to the Mexican expropriation, another form of confiscation which followed a year later", resaltado por la autora de este artículo.

${ }^{26}$ Archivo y Biblioteca Nacionales de Bolivia (ABNB), Fondo Presidencia, 164, 1937; y 263, 1938-1939; "Campaña en favor de YPFB en Sucre", El Diario, La Paz, 3 de abril de 1938: 3; "El interés nacional y los crumiros de la Standard Oil”, Reivindicación. Vocero Semanal de Información Obrera, Sucre, 28 de marzo de 1938: 3; AHSRE, 30-3-15, Legación Bolivia, informes políticos reglamentarios, 1938. La adhesión obrera al nacionalismo petrolero se sigue en lo general en Gallego 191 y ss.

27 "No ha fallado la Corte Suprema el asunto de la Standard Oil Company. La noticia dada a conocer ayer se refiere a una decisión del Supremo Tribunal dela República de México", La Calle, La Paz, 29 de julio de 1938: 4 .

${ }^{28}$ AHSRE, LE 557, Telegramas intercambiados entre Secretaria y A. Rosenzweig, 4 y 16 de mayo de 1938.
} 
resalta la coincidencia entre estas declaraciones y las deliberaciones en Buenos Aires por una paz definitiva con Paraguay (firmada el julio 21 de 1938): en ese contexto, las declaraciones del ministro de Minas y Petróleo y director de YPFB probablemente estaban más bien dirigidas a la audiencia rioplatense y andina, antes que a la atención de los mexicanos. Ya para entonces, la expropiación petrolera había captado la atención de la prensa mexicana en los asuntos del Chaco, considerando además que el país había participado en la mediación diplomática de la Sociedad de Naciones. El empantanamiento de las negociaciones de paz y su vinculación con los asuntos petrolíferos fue oportunamente señalado, en un esbozo de campaña de opinión internacional, por una carta firmada por intelectuales connotados de la izquierda mexicana, universitarios y la Confederación Campesina, que se publicó en junio de 1938 simultáneamente en el Distrito Federal y en Buenos Aires, justo cuando Paraguay había presentado una nueva propuesta de fijación territorial que estancaron las negociaciones. ${ }^{29}$ Es decir, mexicanos y bolivianos comenzaban a replicar en la prensa, en una dinámica refleja, sus controversias internacionales.

En Bolivia, intereses diversos filtraron el proceso de reconocimiento y difusión periodística de la expropiación en México: fueron resaltados unos aspectos de la situación mexicana e ignorados otros. Por ejemplo, mientras se destacaron sus dimensiones diplomática, comercial y financiera, la relevancia de la movilización social y obrera de la expropiación, así como el papel del Estado como regulador y árbitro de las relaciones laborales en favor de los trabajadores quedaron marginados de la atención del periodismo liberal paceño, a excepción de cierta prensa progresista. Este sesgo adquiere relieve si se consideran los debates de la convención en materia social. ${ }^{30}$ Empero, hubo reacciones en respuesta al episodio petrolero mexicano, en el marco del apogeo organizativo del sindicalismo (Lora 7-25). Las organizaciones obreras de Sucre, La Paz y Oruro hicieran llegar a la legación mexicana en La Paz cartas de apoyo y solidaridad al movimiento obrero mexicano y al presidente Cárdenas, entre marzo y agosto de 1938, y en especial para la celebración del 1ㅇ de mayo de ese año. ${ }^{31}$ Grupos organizados de obreros y clases populares

\footnotetext{
29 "16 asociaciones de la ciudad de México temen se reanude la campaña del Chaco Boreal”, La Calle, La Paz, 25 de junio de 1938: 5.

${ }^{30}$ El antifascista e impulsor de campañas de opinión favorables a la República española, Crónica, tituló: "Obreros mexicanos en posesión de las petroleras", Crónica, La Paz, 21 de marzo de 1938: 1. Retomamos aquí la caracterización de la prensa boliviana y sus alineamientos políticos e ideológicos de Knudson.

31 “La Confederación Sindical de Trabajadores de Bolivia, considerando que, ante la estupenda conciencia revolucionaria que encarna el pueblo mexicano, en el gran experimento socialista que triunfa con la
} 
expresaron, en su adhesión a la causa petrolera mexicana, una lucha común contra el capitalismo petrolero internacional y una identificación entre ambos conflictos: parecía que, a sus ojos, la marcha de la causa judicial de la Standard Oil de Bolivia podía quedar determinada por los avatares de los petróleos mexicanos.

Ahora bien, si estas repercusiones populares encontraban extendida raíz en la situación y dinámicas sindicales locales -conectadas a su vez con el desenvolvimiento del movimiento obrero internacional- se explican también por el esfuerzo propagandístico de la diplomacia mexicana y por la campaña por parte de la organización obrera central de México, la Confederación de Trabajadores de México (CTM), que exhortaba a sus pares latinoamericanos a apoyar la expropiación. ${ }^{32}$ Desde la perspectiva del gobierno y del reciente Partido de la Revolución Mexicana, los apoyos internacionales, especialmente los latinoamericanos, contribuían a consolidar los argumentos de México en su controversia internacional con las compañías (Kiddle y Zuleta XII-XXIV). La CTM, por su parte, comprometida en impulsar el apoyo popular internacional en favor de la expropiación, convocó, impulsada por la coyuntura y recurriendo al discurso de la lucha antimperialista, a una reunión o congreso para constituir una organización obrera latinoamericana. Así, a instancias de la propaganda obrerista que irradiaba desde México, concurrieron dos delegados obreros por la CSTB al Congreso Obrero Latinoamericano (México, 5 al 7 de septiembre de 1938): Bernabé Villareal y Román Vera Álvarez. ${ }^{33}$

\footnotetext{
dirección inteligente del camarada Cárdenas, resuelve adherirse al apoyo unánime y colectivo con que todos los obreros organizado de América [...] vienen reforzando la actitud y medida enérgica del c. Cárdenas al decretar la expropiación de las riquezas petrolíferas a favor de la Nación mexicana [...]", 1 de mayo de 1938, en AHSRE, LE 557, Alfonso de Rosenzweig Díaz a Secretaría de Relaciones, "Voto de simpatía al presidente Cárdenas con motivo de la expropiación de las petroleras", 18 de mayo de 1938.

32 "Trabajadores mexicanos piden apoyo para su lucha contra las empresas petroleras", Frente Popular, Santiago, 16 marzo 1938: 4; “Obreros y estudiantes mexicanos en la defensa de su soberanía nacional”, Frente Popular, Santiago, 23 de marzo de 1938; "Una carta del presidente del Partido de la Revolución Mexicana", Acción, Montevideo, junio de 1938; "Rutas continentales: la independencia económica de México", El Universal, Caracas; consultados en Kiddle y Zuleta 108-110, 442-443, 475-477.

33 “Confederación Sindical de Trabajadores de Bolivia”, El Popular, México, 9 de septiembre de 1938; La Prensa, México, 7 de septiembre de 1938. El congreso obrero reunido en México, resolvió la creación de la CTAL (Confederación de Trabajadores de América Latina), con la presidencia de Vicente Lombardo Toledano, líder de la CTM, comprometido en la militancia antifascista. Consultado en Álbum informativo nacional. Congresos internacionales convocados por la Confederación de Trabajadores de México. México D.F, mayo-septiembre 1938, Fondo CCCXVIII, vol. 2, Centro de Estudios de Historia de México CARSOFundación Carlos Slim.
} 
En la prensa de La Paz, la expropiación mexicana recibió considerable atención dentro del conjunto de las noticias internacionales, aunque el impacto exacto sea difícil de medir más allá de lo publicado, es decir, de lo ofrecido al público (Knudson 2). ${ }^{34}$ Obtuvo varias primeras planas, en particular cuando se complicó el trato diplomático con Gran Bretaña a consecuencia de la presión de la Compañía El Águila. Mayor interés causó la ruptura de relaciones con Gran Bretaña, en el mes de mayo de 1938, que alcanzó gran impacto periodístico siendo recibida con asombro por los lectores, en la medida que mostraba decisión y autonomía ante los dictados de las potencias.

Las lecturas periodísticas fueron variadas y estuvieron atravesadas por determinaciones diversas: los horizontes ideológico-discursivos de cada periódico en cuestión, la coyuntura política particular del escenario boliviano entre los meses de marzo a octubre de 1938, y posiblemente las redes políticas e intelectuales de los redactores y editores. Ni siquiera los periódicos próximos a la élite minera tradicional, La Prensa y El Diario, publicaron artículos clara y definidamente hostiles a lo acontecido en México, aunque sí críticos. ${ }^{35}$ Las notas publicadas se detuvieron, principalmente, en las siguientes cuestiones: 1) la repercusión internacional de la medida del presidente Cárdenas, ${ }^{36}$ 2) la influencia que podía tener el acontecimiento mexicano sobre el posible curso de las cuestiones económicas y petroleras bolivianas; ${ }^{37} 3$ ) las similitudes entre la situación, los intereses y necesidades

\footnotetext{
${ }^{34}$ Considero que la prensa es una fuente histórica relevante pese al analfabetismo y alto porcentaje de población rural: es constitutiva de la cultura política y generaba parte importante de los enunciados que circulaban en la opinión pública, que eran luego reproducidos, transmitidos y re significados en el debate político amplio y popular. Véase Knudson 2-3.

35 Por ejemplo, "México y la expropiación", La Razón, La Paz, 1 de junio de 1938: 7; "Estados Unidos toma represalias contra México", La Razón, La Paz, 28 de marzo de 1938: 1. Por ejemplo, "México y la expropiación", La Razón, La Paz, 1 de junio de 1938: 7. "EE UU suspenderá sus compras de plata a México", Crónica, La Paz, 28 de marzo de 1938: 1. "El gobierno de Lázaro Cárdenas responde de forma interesante", La Razón, La Paz, 19 de abril de 1938: 6.

${ }^{36}$ Los periódicos La Razón, El Diario y Crónica, en menor medida La Calle, siguieron con especial atención las reacciones de la diplomacia británica y estadounidense, así como las consecuencias económicas de la expropiación, particularmente las represalias comerciales y cambiarias. Por ejemplo: "Defensa de los intereses del pueblo de México a los trusts de petróleo", El Diario, La Paz, 9 de julio de 1938: 2; "Son vidriosas las relaciones entre México e Inglaterra", La Razón, La Paz, 2 de mayo de 1938: 6.

${ }^{37}$ Ello respecto a dos puntos: la oferta de capital, tecnología y mercados para el desenvolvimiento de la explotación estatal de petróleos y la cuestión de la indemnización a la Standard. Por ejemplo, "Capitalistas belgas desean explotar riquezas petroleras", Crónica, la Paz, 12 de abril de 1938: 5; "EEUU reconoce el derecho de México", Crónica, La Paz, 31 de marzo de 1938; "Estados Unidos, futuro comprador de estaño de Bolivia. Prestará su más decidida cooperación en el acuerdo tendiente a facilitar a Estados Unidos esta materia prima", La Razón, La Paz, 10 de mayo de 1938: 10.
} 
económicas y políticas de México y Bolivia; ${ }^{38}$ y 4) su significación como posible o potencial ejemplo a imitar o a evitar. ${ }^{39}$

La prensa conservadora llamó la atención sobre la supuesta vinculación de la expropiación con los intereses comerciales del bloque fascista, buscando crear la idea de que el petróleo mexicano iba a ser aprovechado por los fascismos y no por los intereses democráticos. ${ }^{40}$ Sin embargo, unos meses después, periódicos como La Razón señalaron al público lector un aspecto de la expropiación mexicana que servía a los intereses de la élite minera: la indemnización que el presidente Cárdenas se había comprometido a dar a las compañías. Los poderosos mineros, al advertir el rechazo que una posible reversión de la incautación a la Standard causaba entre la población, apostaron a dos estrategias: por un lado, el desgaste de los gobiernos militares autoproclamados socialistas $y$, por otro, una campaña de prensa que apuntalara el reconocimiento de las reclamaciones de las compañías. Mediante ello, los intereses de la minería pretendían sostener los principios del derecho de la propiedad privada, que consideraban amenazados por un creciente control fiscal sobre sus exportaciones (Ayub \& Hashimoto 13) y simultáneamente robustecer sus negocios con Estados Unidos. Por otro lado, algunos sectores de la oficialidad militar, alentados también por el grupo de capitalistas vinculados al grupo Hochschild, impulsaban los vínculos con Italia y Alemania. En realidad, las preocupaciones de los barones del estaño se dirigían a la audiencia estadounidense y a los intereses de los empresarios de ese país: ese mercado despuntaba al lado del europeo desde la década del veinte, cuando inició la participación accionaria de Patiño en la National Lead Co. y se construyó en Delaware una gigantesca fundición, la Patiño Mines Enterprises, vinculada al complejo industrial automotriz (Ayub \& Hashimoto 12).

Más allá de lo visible en la prensa, hacemos notar que los diplomáticos y los grandes intereses empresariales de las industrias extractivas, de la minería y el petróleo, conectaron las experiencias nacionalistas de Bolivia

\footnotetext{
38 "La nacionalización, independencia de los pueblos", El Debate, La Paz, 23 de marzo de 1938; "Similitudes con México", La Calle, La Paz, 15 de mayo de 1938: 1; “La nacionalización del petróleo", El Diario, La Paz, 23 de junio de 1938: 9.

39 "En la cuestión de petróleos México da un nuevo ejemplo", La Calle, La Paz, 10 junio 1938: 4. "Impresiones del Ministro de Bolivia en México sobre el grado de progreso que alcanzó la República azteca”, El Diario, La Paz, 20 de marzo de 1938: 6.

40 “México venderá su petróleo a los países de tipo totalitario”, El Diario, La Paz, 21 de julio de 1938: 1.
} 
y México. Como vimos, la Standard Oil prefirió, al menos entre 1937 y 1938, soportar pérdidas financieras antes que dejar precedentes en materia de negociación acerca de los derechos de propiedad que resultaban afectados, pues ello implicaría "una futura inseguridad para las propiedades americanas en toda Latinoamérica" (Rodman 113) ${ }^{41}$. Y, a la luz de los acontecimientos mexicanos de marzo del 38, la cuestión de la santidad de los derechos de propiedad de los capitalistas bolivianos y extranjeros motivó un fuerte debate entre las diversas agencias de la burocracia estadounidense, y un paulatino cambio en la postura inicialmente distante de su diplomacia con respecto a la incautación.

Es así que la sucesión entre la incautación boliviana y la expropiación mexicana -y la interconexión entre ellas- derivó también en una serie de ajustes diplomáticos por parte de Estados Unidos, precipitando, hacia 1939, el endurecimiento del Departamento de Estado frente al gobierno boliviano: este Departamento abandonó su distancia inicial, para cobijar los reclamos de la Standard en pos de una indemnización o compensación (Rodman 119). Ante ello, y también debido al contexto bélico europeo, el gobierno mexicano se ocupó de que la prensa capitalina reparara, tardíamente, en que "el caso petrolero de Bolivia tiene una serie de similitudes con el de México". ${ }^{42}$ Meses después, folletos publicados en Estados Unidos por diplomáticos bolivianos, desmentían toda analogía entre ambas experiencias, con el objetivo de gestionar una resolución pronta para el caso de reclamación de la Standard, a la luz de nuevas prioridades: la negociación de un posible acuerdo para el comercio de estaño (Guachalla 30). ${ }^{43}$

Entre tanto, la élite económica boliviana había conseguido formular representaciones nacionalistas de los acontecimientos petroleros boliviano y mexicano -dirigidas a la audiencia andina- y plasmarlas en la forma de un ambiguo discurso nacionalista de corte conservador: la tesis de que la expropiación mexicana había tomado el modelo boliviano de la incautación a la Standard. Finalmente esta apreciación se difundió en la prensa boliviana, alcanzando recepción entre aquellos sectores de la opinión que -admirando los logros agraristas, indigenistas, sociales y culturales de la revolución

\footnotetext{
${ }^{41}$ Versión libre del inglés, por la autora.

${ }^{42}$ Biblioteca Lerdo de Tejada, AEH, del titular de El Universal, 14 octubre de 1939, declaraciones del subjefe del Estado Mayor Presidencial Othón León Lobato, al recibir en una ceremonia de agasajo al primer embajador de Bolivia en México, Enrique Finot (véase más abajo).

43 "La Standard Oil Co. y otros comentaristas creen ver o pretenden sugerir que lo acontecido en Bolivia tiene perfecta analogía con los sucesos de México. Hay aquí un grande error, por ignorancia o por malicia”.
} 
mexicana- pretendían seguir itinerarios mexicanistas para la revolución que esperaban pudiera librar a Bolivia de su postración histórica. ${ }^{44}$ Incluso la radio fue vehículo de esta compleja compenetración entre discursos nacionalistas. Por ejemplo, el Sindicato de Choferes de Sucre emitía por entonces dos programas semanales (lunes y viernes) por radio Chuquisaca, con fines de pedagogía política y adoctrinamiento, referentes la cuestión del petróleo, donde se trataba el caso mexicano:

[...] la cuestión petrolera está siendo tomada por el Sindicato de Choferes en una forma en que ni la YPFB viene haciéndolo [...] las audiciones no sólo se refieren a reproducir una historia del petróleo nacional, sino que tocan el problema en el mundo, sintetizando el caso de Méjico con una habilidad y conocimiento completos $[\ldots]^{45}$.

Tal como señaló el entonces responsable de la diplomacia boliviana en México, Alfredo Sanjinés, en un informe detallado sobre "La nacionalización del petróleo en México", de fecha 14 de abril de 1938, el "ejemplo para Bolivia" residía no solamente en el nacionalismo petrolero mexicano, sino en su divulgada apariencia de fortaleza:

Mientras México ha dado, como siempre, un ejemplo de nacionalismo y de independencia a los países latinoamericanos y lo ha hecho en términos que deben merecernos una cuidadosa observación [...] la significación que tienen las actitudes resueltas y definitivas y el respeto que merecen por todas las conciencias libres del mundo; y aún en las actuales reclamaciones de la Standard Oil [...] concretamente, por el temor que pudiera abrigarse por la falta de apoyo de Estados Unidos a Bolivia en la cuestión del Chaco, si es que nuestro país se pone francamente en defensa de sus intereses, [...] siempre inspirará más respeto una política digna y valiente de un país soberano... Méjico está dando el ejemplo... ${ }^{46}$.

Finalmente, las resonancias de la experiencia mexicana en la opinión boliviana no se desvanecieron en el tiempo. Dos décadas después, Sergio

\footnotetext{
${ }^{44}$ Sobre la relación entre la expropiación mexicana y boliviana, y la discusión sobre la originalidad de cada una ver: "El turno de Bolivia. Elogio sobre el decreto de caducidad de las concesiones de la Standard Oil", El Nacional, México, adjunto en Informe del Encargado de Negocios Carlos Dorado Chopitea a Diez de Medina, 21 de abril de 1939, AHMREB, Embajada de Bolivia en México.

45 “La cuestión petrolera. La labor del Sindicato de Choferes”, Adelante!, Sucre, 3 de abril de 1938: 3.

${ }^{46}$ Alfredo Sanjinés, "Informe sobre la nacionalización del petróleo en México", 18 de mayo de 1938, AHMREB, Correspondencia de México.
} 
Almaraz Paz, en su obra clásica Petróleo en Bolivia, señalaba el caso del nacionalismo petrolero mexicano como una de las tres experiencias, junto a la argentina y venezolana, digna de tomarse en cuenta para inspirar el debate en torno al régimen de explotación de los hidrocarburos bolivianos (Almaraz Paz 66-85).

\section{Pulsaciones revolucionarias encontradas}

La decisión expropiatoria mexicana no sólo generó repercusiones periodísticas y expresiones de adhesión en el sector obrero, intelectual y militar en Bolivia, sino además una creciente proximidad diplomática. Si ello respondía a conveniencias recíprocas de ambos gobiernos, pudo concretarse gracias a las iniciativas del gobierno de Germán Busch (1937-1939), que retomaban gestiones iniciadas por su predecesor.

Tras derrocar a David Toro en julio de 1937, el presidente Germán Busch había declarado su decisión de mantener -y reafirmar- la incautación de las propiedades e instalaciones petrolíferas de la Standard Oil. Meses después, declaró su apoyo al presidente Lázaro Cárdenas en su lucha por la soberanía, afirmando que consideraba "proclamaba la revolución y regeneración de la Nación tal como él mismo se lo proponía para la Nación Boliviana" 47 , además fue quizás el único presidente latinoamericano en manifestar una opinión positiva acerca de la expropiación mexicana. ${ }^{48}$ Mediante estas declaraciones formuladas a mediados de 1938, el presidente Busch sintetizaba algunas metas de más amplio alcance: por un lado, transmitía su posición de mantener una línea nacionalista en materia minera y petrolera y de no revertir la incautación de la Standard. ${ }^{49}$ Por otro lado, anunciaba, en el preciso momento en que se reunía en Buenos Aires la Conferencia de $\mathrm{Paz},{ }^{50}$ su inclinación por imprimir nuevas pautas a la política

\footnotetext{
47 Informes políticos correspondientes a 1938, 30-3-15; y 31-24-5; "Bolivia está con nosotros", 21 de septiembre de 1938, AEH, Biblioteca Lerdo de Tejada.

${ }^{48}$ Hasta donde se tiene conocimiento en la documentación disponible.

${ }^{49}$ Este comunicado fue difundido por la prensa mexicana de inmediato, "El régimen socialista en Bolivia. El presidente del gobierno provisorio no hará concesiones a la Standard", AEH, Biblioteca Lerdo de Tejada, s/f.

${ }^{50}$ La paz con el Paraguay se firmó, finalmente, después años de negociaciones intrincadas, el 21 de julio de 1938. Fabián Herrera explica en un novedoso estudio que México había participado durante las hostilidades como mediador desde la Sociedad de Naciones.
} 
exterior. Todo ello tenía alta relevancia considerando la gran complejidad de las vinculaciones de Bolivia con sus vecinos: Argentina, Brasil y Chile. ${ }^{51}$

En segundo término, sus declaraciones se dirigían al público interno con mensajes tanto para la oposición de derechas como para los grupos de la izquierda más radical. El horizonte de su gobierno se anunciaba así revolucionario, pero prefiguraba una revolución nacionalista, no comunista, tal como la revolución mexicana. ${ }^{52} \mathrm{Al}$ mismo tiempo, al resaltar la inspiración mexicana, distraía la atención de la presencia de militares y policías alemanes e italianos en el país, un indicador de las inclinaciones pro fascistas de algunos grupos del ejército. ${ }^{53}$

El presidente boliviano persistió en esta estrategia discursiva, a pesar del marasmo político de 1938: acosado por la erosión de los partidos políticos tradicionales, por la crisis económica, por las movilizaciones populares (obrera y universitaria), por la radicalización de los grupos de izquierda (ante la crisis y el debate sobre el régimen social y económico financiero en la Convención) y el boicot de la derecha, que logró evitar el debate profundo sobre el trabajo forzado y la situación agraria en la Constituyente (Gallego 30-100). Incluso podría afirmarse que el tratamiento que dio a los asuntos mexicanos fue discretamente estratégico a efectos de manejar estas tensiones internas.

Por ejemplo, en junio de 1938, justo en arduos momentos en las sesiones de la Convención, Bush consiguió dar relieve simbólico a estos proyectos de acercamiento: el 5 de junio de 1938 el encargado de la legación de Bolivia en México, Alfredo Sanjinés, entregó a Lázaro Cárdenas, en nombre de su gobierno y del presidente Busch, una condecoración especial, el Cóndor

\footnotetext{
${ }^{51}$ Se discutió la adopción de nuevas orientaciones internacionales, basadas en prioridades afincadas en los intereses y necesidades económicas y culturales antes que territoriales y geopolíticas, como se puede observar en Holland. En esa línea, entre 1937 y 1939, se firmaron varios convenios de comercio, transportes, cooperación cultural y técnico-profesional con los países vecinos, los cuales fueron seguidos en detalle por la legación mexicana en La Paz.

52 Para un panorama sobre las acusaciones de comunismo mexicano en Latinoamérica véase Palacios, capítulo "Los años rojos", 235-270.

53 "Es precisamente el temor de que el auge de las derechas en ese continente pueda relajar las tendencias izquierdistas del actual régimen boliviano y hacerlo inclinarse súbitamente hacia el extremo contrario, el factor que más ha influido a nuestro gobierno para acrecentar su acercamiento con el de Bolivia, ya que se considera que el apoyo que el régimen boliviano encuentre en el de México podrá hacer contrapeso quizás a los trabajos tendenciosos de Estados vecinos", AHSRE, México, 30-3-16, Informes políticos 1938, Secretaría de Relaciones Exteriores al ministro Rosenzweig Díaz.
} 
de los Andes, en grado de Gran Cruz. ${ }^{54}$ Sanjinés se trasladó a San Luis Potosí, centro de la revuelta del caudillo Saturnino Cedillo, contraria a Cárdenas y a la expropiación. Allí, el ministro, conocedor de la reforma agraria mexicana y partidario de la idea de fertilizar los proyectos de reforma social agraria boliviana con el ejemplo mexicano (Sanjinés 42-63, 154-162), expresó la voluntad de su país de formalizar un rango más alto de Embajada para su representación diplomática en México, afirmando:

El Gobierno de Bolivia ha resuelto fortalecer los vínculos que lo ligan a vuestra nación, porque entiende que la aproximación hacia México no es para los pueblos indoamericanos el resultado de conveniencias de orden material, sino el trasunto de un pasado fecundo y de un porvenir que vosotros estáis demostrando cómo se traduce en acción [...] Bolivia sigue atentamente el proceso constructivo de vuestro Gobierno, cuya política social y económica es de tal magnitud, que casi podríamos decir que de su éxito o fracaso dependen el porvenir político, social y económico de los pueblos latinoamericanos [...] vuestra sensibilidad os ha apegado a las tradiciones de nuestras razas indígenas y al mejoramiento de las masas campesinas desvalidas. Vuestra política social, amplia y generosa, os ha elevado a la altura del vuelo el Cóndor de los Andes, que es la insignia de esta condecoración boliviana. ${ }^{55}$

La respuesta de Lázaro Cárdenas confirma el interés del presidente de aprovechar la coyuntura de controversia petrolera, amenazada por el cuestionamiento de las compañías y de la diplomacia británica, ${ }^{56}$ y por la rebelión de un caudillo regional, para convertir a México en una especie de modelo revolucionario nacionalista e indigenista. Así quedó expresado en el discurso de Cárdenas, en el que se replican imágenes del dilema andino en torno a la identidad mestiza o indígena. ${ }^{57}$ Los reflejos periodísticos en la

\footnotetext{
54 La primera en Latinoamérica, puesto que por entonces todavía en Chile y Argentina se mantenían legaciones, con ministros a cargo, no embajadores. En particular, el periódico de izquierda nacionalista La Calle, refiriéndose a la rebelión de Cedillo, tituló "Similitudes con México", 17 de mayo de 1938 (equiparando la presión de las petroleras británicas con las de la Standard y la Rosca minera), y "Traición en México", 21 de mayo de 1938: 4.

${ }^{55}$ Resaltado por el autor. Condecoración del Cóndor de los Andes al C. Presidente de la República General Lázaro Cárdenas. Discurso del excelentísimo señor Ministro de Bolivia, Alfredo Sanjinés y contestación del C. Presidente de la República General Lázaro Cárdenas. México: 1938, 7 y 8.

${ }^{56}$ La ruptura de relaciones de México con Gran Bretaña había tenido lugar en mayo de 1938. La Calle, La Paz, 18 de mayo de 1938: 1.

${ }^{57}$ Cárdenas respondió: "[...] los esfuerzos de Bolivia y de México para incorporar su población indígena a la vida nacional y para abrir un amplio camino de reivindicaciones y de oportunidad a las razas que por todos conceptos las merecen, vuelven aún más afines a nuestros países porque el aspecto indígena es el que ha modelado la fisonomía de los pueblos de América Hispana. Ni españolas, ni indígenas puras, estas jóvenes naciones de la América son mestizas; mestizas en sangre y en espíritu, herederas de dos civilizaciones en
} 
captación de este discurso fueron inmediatos, tanto en los Andes como en México. ${ }^{58}$

Más allá del simbolismo de la condecoración y la alusión al vuelo del Cóndor, la proximidad diplomática con el gobierno de México coincidió además con un intenso movimiento en paralelo de acercamiento con los gobiernos de Perú, Chile y Brasil, en pos del desarrollar una cooperación cultural y económica, demostrando ello intereses centrados en conveniencias diplomáticas antes que en afinidades ideológicas, por parte del gobierno de Bolivia (Holland). ${ }^{59}$ Desde la perspectiva del gobierno de Cárdenas, la condecoración en momentos de rebelión interna brindaba mensajes, ante la opinión mexicana, del prestigio y reconocimiento internacional obtenido, asunto de importancia política pese a su intangibilidad (Kiddle 2010). Un año después, antes de la partida de Sanjinés, Cárdenas le entregó la Medalla del Águila Azteca, en tercer grado. ${ }^{60}$

Estos tratos cercanos derivaron en la elevación del rango de la representación diplomática de ambos países, al año siguiente (anunciada en enero, se concretó en abril de 1939), siendo el primer embajador asignado por Bolivia el Dr. Enrique Finot, uno de los más experimentados y prestigiosos diplomáticos bolivianos. Este hecho indica la relevancia que alcanzaba la relación con México en sí misma, vista desde el mirador andino, pero también la significación de México como palanca para obtener mayor fluidez en las relaciones con Estados Unidos: Finot resultaría un operador privilegiado de los negocios entre Bolivia y Estados Unidos, a través de los conductos mexicanos.

\footnotetext{
pugna que, finalmente han encontrado la síntesis que constituye la personalidad peculiar de cada una [...]". La Calle, La Paz, 18 de mayo de 1938: 9-10.

${ }^{58}$ Excélsior (México) tituló, al día siguiente, 6 de junio de 1938: "Está pendiente la América del éxito o fracaso en la política social de México. Comunidad de propósitos y problemas". Mientras la prensa de Sucre y La Paz transcribía los discursos de la ceremonia, ésta repercutió en la región: por ejemplo, El Frente Popular, de Santiago, publicó “Bolivia condecoró al presidente Cárdenas de México". Santiago de Chile, 6 de junio 1938: 2 .

${ }^{59}$ El acercamiento del gobierno de Bolivia al de Lázaro Cárdenas podría leerse como un intento de autonomía frente a la presión geopolítica y económica ejercida por los poderosos vecinos, Argentina, Chile y Brasil, y así lo comprendió el ministro Rosenzweig. Se requeriría una investigación específica, que excede los alcances de este texto.

${ }^{60}$ A. Sanjinés a E. Diez de Medina, 5 de abril de 1939; en Correspondencia de la Legación de Bolivia en México, por correo aéreo, AHMREB, "Se despide un gran amigo de México", El Nacional, 2 de abril de 1939.
} 
Ahora bien, la coyuntura petrolera mexicana hizo posible que se consolidara temporalmente esta aproximación diplomática; no obstante, los orígenes de esta preceden al episodio del 18 de marzo de 1938. A la luz de un esfuerzo expreso de la diplomacia mexicana por lograr presencia en Sudamérica desde mediados de la década del treinta, se había forjado un sustrato de vinculaciones previas, entre las cuales cabe desatacar la participación de México como mediador en la contienda del Chaco (Herrera 127-166). ${ }^{61}$ Influencia fundamental tuvo el incansable trabajo desarrollado por el ministro Alfonso de Rosenzweig (1936-1938), impulsando la vida cultural boliviana. Sus gestiones habían fructificado en la articulación de vínculos con la intelectualidad progresista de la Paz, Sucre y Potosí, ${ }^{62}$ e inclusive en la activa labor de promoción editorial de autores mexicanos y bolivianos, como se puede observar en la Revista México. A través del mecenazgo cultural y de campañas propagandísticas pro México, en las que se exaltaban los logros de la Revolución tanto en el ámbito doméstico como en el internacional, ${ }^{63}$ para contrarrestar los cuestionamientos de la derecha boliviana a la política religiosa y educativa del gobierno de Cárdenas, ${ }^{64}$ Rosenzweig creó lazos con los responsables de la nueva política educativa indigenal. Asimismo colaboró en los preparativos para la organización del Primer Congreso Indigenista Interamericano, que se planeaba realizar en La Paz a mediados de $1938 .{ }^{65}$ En esa labor -y en el apoyo que en representación

\footnotetext{
${ }^{61}$ Por ejemplo, la repercusión de la reforma agraria mexicana en los conflictos agrarios de Bolivia: en una nota de septiembre de 1932, "Indígenas de Bolivia se dirigen al representante de la noble Nación de Méjico", en petición de su intervención por la Paz con el Paraguay, AHSRE, 27-29-13, Revista política 1936, noviembre”.

${ }^{62}$ AHSRE, Informes políticos, 1936, 27-29-13 y 27-29-14; “El socialismo en marcha. La educación de las masas ha recibido mayor impulso y nueva orientación”, La Hora, Sucre, 6 de marzo de 1937: 5; "El socialismo en marcha. La Reforma Agraria en México", La Hora, 7 de julio de 1937; "La Biblioteca de la Revista México", Adelante!, Sucre, 22 de junio de 1938: 3.

${ }^{63}$ Los ejes de la propaganda mexicana, que colocaban México como la avanzada de la revolución social en el continente, fueron: la reforma agraria, la educación socialista, la redención del indio a través de la educación, el arte y literatura revolucionarios, en el ámbito interno, y en el internacional, la lucha por la autodeterminación de los pueblos, la paz y la adhesión a los principios del derecho internacional y la democracia, junto a la defensa de la República española. En diciembre de 1936 se organizó una "Semana de México" en La Paz, con la participación de intelectuales de izquierda y socialistas, donde se vitoreó también a la República española, AHSRE, 27-29-13, Revista política, diciembre. Importante es notar que también hubo voces críticas desde la izquierda, como el mencionado Tristan Marof.

${ }^{64}$ Véase Palacios 235-270. En la prensa de Bolivia: “Los derechistas mexicanos acusados de pretender derrocar al general Cárdenas", El Diario, La Paz, 21 de noviembre de 1937: 1, titular.

${ }^{65}$ Una delegación magisterial viajó a México en noviembre de 1937, encabezada por el subsecretario del ramo de Asuntos Indígenas, Rafael Reyeros. La misión enfrentó dificultades y descuido por parte de la burocracia mexicana, Rosenzweig a Hay, 22 de noviembre de 1937, en AHSRE, exp. III-29-59-3. Pronto quedaría claro
} 
y con fondos del gobierno mexicano otorgó para la construcción de una maestranza en la escuela indigenal de Warizata- el diplomático mexicano logró participar, indirectamente, en el profundo debate que tenía lugar en Bolivia en torno al concepto y métodos de la educación indígena y las formas y modalidades de integración de dicha población (Giraudo 520). ${ }^{66}$

Los nexos que logró articular Rosenzweig habían conseguido crear el fermento para el intercambio recíproco de misiones magisteriales entre ambas naciones, entre 1937 y 1938, y también para otras experiencias de cooperación técnica y educacional, que dieron lugar al desenvolvimiento de redes intelectuales y científico-técnicas que, si bien efímeras y de éxitos modestos, se retomarían bajo otro contexto en los gobiernos del MNR. Esta cooperación, que denominamos "cooperación revolucionaria", se centró en puntos nodales de la agenda de transformación económica y social boliviana que también México venía enfrentado desde décadas anteriores, en los siguientes ámbitos: derecho y economía agraria, cooperación educativa (rural e indígena, superior universitaria y militar), científica (ciencias de la tierra, ciencias biomédicas y sanitarias) y técnica (ingeniería hidráulica, otra de las banderas de la revolución mexicana, la "irrigación revolucionaria", e ingeniería en caminos). ${ }^{67}$

Es relevante, desde nuestro enfoque, constatar que la coincidencia de la expropiación petrolera mexicana con la agenda de reformas del gobierno de Germán Busch redundó, finalmente, en la concesión de varias becas para estudiantes bolivianos en la Universidad Nacional Autónoma de México

\footnotetext{
que, no obstante sus apoyos a los proyectos de educación indigenista, los mexicanos querían el pendón de campeones del indigenismo para sí solos (aunque las gestiones del ministro Rosenzweig en Bolivia fueran generosas y espontáneas), en lo cual quizás no fueron ajenos los intereses de los Estados Unidos, puesto que su delegación tuvo una importante presencia en el proyectado Congreso Indigenista, que finalmente se realizó en Pátzcuaro, México, casi terminando el mandato del presidente Cárdenas en abril de 1940.

${ }^{66}$ Rosenzweig trabajó además conjuntamente con Elizardo Pérez, fundador de la experiencia Warizata, en la comisión responsable de los preparativos para el Congreso Indigenista, programado para 1938, pero pospuesto para realizarse en México.

${ }^{67}$ AHSRE, exp. 11418, Rosenzweig a Hay, 20 de octubre de 1938, informando del apoyo del exdirector del Banco Central, Casto Rojas, a la construcción de obras hidráulicas en Cochabamba, y del acuerdo de colaboración de ingenieros hidráulicos mexicanos. Sobre la "cooperación revolucionaria" en materia educativa cabe mencionar, además, Embajada de Bolivia en México, 1939, abril 24 de 1939, encargado de negocios Carlos Dorado Chopitea a Diez de Medina, "Ingenieros mexicanos" y "La vinculación mexicano-boliviana", Alfredo Sanjinés a Diez de Medina, enero 4 de 1939 en AHMREB, sin ordenar; AHSRE, exp. 11418, Rosenzweig a Hay, 20 de octubre de 1938.
} 
(UNAM), en las áreas de ciencias de la tierra e ingeniería en petróleos. ${ }^{68}$ Ello resulta especialmente significativo y muestra clara voluntad política por sostener el componente petrolero de la interrelación cultural y científica mexicano-boliviana, en la medida en que la carrera de ingeniería en petróleos se había establecido en México apenas a mediados de la década del veinte (Baptista González, cap. 3). Si se tiene en cuenta, además, la proximidad existente en esos años entre la gerencia y directivos de YPFB y su par YPF argentino, mediando convenios de colaboración boliviano-argentino en el campo de la producción y comercialización de petróleo con el país del Plata, adquiere mayor realce la capacitación de ingenieros en México. En este contexto, el nombramiento de Enrique Finot como embajador en México, habiendo sido personaje clave en la gestión diplomática del conflicto por la incautación, como embajador en los Estados Unidos en 1937, resulta iluminador. ${ }^{69} \mathrm{~A}$ ambos gobiernos, al boliviano como al mexicano, podía convenir un frente de propaganda convergente, en respaldo de su diplomacia petrolera. Significativamente, El Universal publicaba en la ciudad de México, el 25 de mayo de 1939, una nota procedente de Buenos Aires, que señalaba:

La expropiación de los yacimientos petrolíferos ha establecido una estrecha comunidad de intereses entre México y Bolivia, y debe recordarse que Bolivia inició las expropiaciones un año antes que lo hiciera México. ${ }^{70}$

Ahora bien, más allá de la retórica, en términos de resultados, la colaboración mexicana al desarrollo de la industria petrolera boliviana fue efímera, al igual que en los otros campos, debido al pronto cambio de coyuntura internacional en 1940, que modificó las prioridades internacionales mexicanas y bolivianas, y al arreglo acordado con la Standard Oil en enero de 1942, en la Conferencia Interamericana de Río de Janeiro, con el que se pretendía facilitar la negociación de los convenios minerales estratégicos con

\footnotetext{
${ }^{68}$ Sobre la "cooperación revolucionaria" en la educación cabe mencionar, además, que los gobiernos mexicano y boliviano negociaban entonces un acuerdo de intercambio universitario con la UNAM para fortalecer las carreras de ingeniería y física en la universidad paceña de San Andrés, con docentes de la UNAM. En consecuencia, YPFB otorgó siete becas en total a estudiantes bolivianos "con el objeto de ingresar a la facultad de ingeniería de petróleos de la Universidad Nacional". AHMREB, Legación de Bolivia en México, 8 de abril de 1938, "Estudiantes petroleros, su llegada”, Alfredo Sanjinés a Diez de Medina. Del mismo fondo ver "Informe de labores de la Legación de Bolivia en México", y "Correspondencia", 1938 у 1939.

${ }^{69}$ AHSRE, 29-30-12 (1941).

${ }^{70}$ AHE, Biblioteca Lerdo de Tejada, "El Ministro de Relaciones Exteriores de Bolivia presentó su renuncia", El Universal, México, 25 de mayo de 1939.
} 
Estados Unidos (Valdivieso y Salamanca 122-178)71. En los prolegómenos de la Segunda Guerra, Enrique Finot informaba desde México acerca de la reasignación de estos estudiantes a un convenio de cooperación académica con centros universitarios de los Estados Unidos, entre ellos, la Universidad de Oklahoma, mientras que a mediados de 1941 una misión técnica estadounidense formulaba un detallado plan de cooperación para el desarrollo del sector agrario, sanitario, minero, industrial y petrolero. ${ }^{72}$

\section{Consideraciones finales}

A lo largo de este texto se ha visto que durante el año 1938, "el año del petróleo" en México, tuvo lugar en Bolivia el reconocimiento, apropiación y adaptación de un nacionalismo revolucionario diferente, como era el mexicano. La dimensión controversial que alcanzó la cuestión petrolera en ambas naciones posibilitó la compenetración en asuntos de materias más amplias, como la agraria y social indígena, y se plasmó en experiencias de cooperación que, si bien de efímera duración y no siempre exitosas en sus resultados, apuntalaron la retórica política y propagandística del cambio económico y social en ambas naciones.

Cabe preguntarse también acerca de las percepciones mexicanas de las disyuntivas que enfrentaba una política petrolera en Bolivia. Estudiosos expertos en el tema han polemizado acerca de la importancia e implicaciones del precedente boliviano a los ojos del presidente Cárdenas y su círculo (Schuler 96). Muy probablemente, las reacciones dispares de las compañías y de la diplomacia estadounidense ante la caducidad de las concesiones a la Standard Oil of Bolivia no pasaron inadvertidas para la élite política mexicana. Además, la medida no encontró reacciones populares extendidas en 1937 en México, aunque, no obstante, obtuvo la detenida atención de A. de Rosenzweig en La Paz. El ministro se encargó de precisar y transmitir a su gobierno diferentes lecturas de la incautación petrolera boliviana de marzo

\footnotetext{
${ }^{71}$ Este arreglo contemplaba el pago de un millón y medio de dólares a la Standard Oil por concepto de compensación y fue aprobado en febrero de mismo año después de controvertidos debates.

${ }^{72}$ Este plan fue conocido como Plan Bohan, por ser coordinado por el analista económico Merwin Bohan, quien unos años después se desempeñaría, también, como consultor económico en la Embajada de los Estados Unidos en México (1945-1949). Precisamente en 1948, se comenzaron a discutir acuerdos de cooperación de la empresa estatal PEMEX con compañías petroleras estadounidenses. Véase Susana Chacón en Rousseau 229-255.
} 
de 1937, desde la conjura nacionalista-militarista hasta la gesta nacional y popular, en voluminosos informes, algunos de los cuales se han perdido en los archivos de las diversas oficinas de gobierno mexicanas.

La idea de una conexión petrolera entre ambas naciones tuvo en este agudo diplomático un impulsor: desde sus oficinas en La Paz, ya en 1936, Rosenzweig delineó conceptos, sugirió estrategias, y propuso argumentos doctrinarios dirigidos a influir y convencer a los círculos gubernamentales mexicanos de la importancia de mirar a Bolivia. Inspirado, simultáneamente, quizás, en el ideario nacionalista de la revolución mexicana y en el diálogo con la intelectualidad nacionalista boliviana con la que se vinculó, como por ejemplo con el grupo editor del periódico La Calle, que encabezaría más tarde la Unión Boliviana de Defensa del Petróleo, el ministro fue elemento importante en la construcción de las representaciones discursivas mexicanas sobre Bolivia, desbordando quizás las directrices de su propia cancillería. Desde el estallido de la guerra civil española, en abril de 1936, los puntos de vista anti fascistas de la diplomacia mexicana marcaron su posición en el Cono Sur. En ese escenario regional controlado por gobiernos conservadores y derechistas -candente no solamente por la guerra del Chaco sino también por el conflicto de España y por la presencia ideológica, militar y comercial de los fascismos europeos- una campaña de propaganda progresista y petrolera en Bolivia significaba el sostén a las fuerzas democráticas no comunistas de la región. ${ }^{73}$

En suma, si bien todavía no conocemos lo suficiente acerca de las conexiones revolucionarias entre México y Bolivia, y sabemos que estas enfrentaron limitaciones no tratadas aquí, ${ }^{74}$ podemos considerar que alcanzaron saldos visibles y palpables, antes y después de la Segunda Guerra, cuando hubo un interregno de enfriamiento en el trato. A partir de los años cincuenta iniciaría un nuevo ciclo de relaciones próximas, cuando el gobierno del MNR emprendió la nacionalización de las minas y una reforma agraria. La revolución nacionalista boliviana iniciada en 1952 abrió nuevamente la posibilidad de una nueva convergencia "revolucionaria", pero en el marco de un mundo bipolar, la cooperación se nutrió más por la técnica que por la propaganda. Era preciso darle un destino agrícola e industrial a la nación

\footnotetext{
73 AHSRE, México, 30-3-16, Legación de México en Bolivia, Informes Políticos Suplementarios, marzo de 1938 , Secretaría de Relaciones Exteriores a ministro Rosenzweig Díaz.

${ }^{74}$ Por ejemplo, complicaciones financieras, pugnas burocráticas en México, inconstancia de las autoridades bolivianas, y malentendidos de orden administrativo, técnico y diplomático, e incluso acusaciones de corrupción, entre otros.
} 
minera encapsulada en los Andes y de nuevo el modelo mexicano era susceptible de emularse, ya que importaba a su vez el aislamiento de las fuentes de inspiración marxistas y comunistas. ${ }^{75}$ Ingenieros agrónomos y en alimentos fueron enviados a Bolivia a colaborar con sus conocimientos sobre derecho agrario y modernización agrícola, ingenieros en petróleos tomaron el itinerario boliviano, al menos para brindar asesorías. ${ }^{76}$ Por entonces, se inauguró oficialmente la Presa México o Presa la Angostura, en la región de Cochabamba, construida con la colaboración de ingenieros mexicanos, que habían llegado a Bolivia a fines de $1938 .{ }^{77}$

\section{Bibliografía citada}

ALMARAZ PAZ, Sergio. 1970 [1958]. Petróleo en Bolivia. Segunda Edición. La Paz: José Camarlinghi.

AYUB, Mahmood Ali \& Hideo Hashimoto. 1985. The Economics of Tin Mining in Bolivia. Washington, DC: The World Bank.

BAPTISTA GONZÁLEZ, David. 2007. “La creación de la primera carrera de ingeniero petrolero en la Universidad Nacional". Tesis de licenciatura. México: Universidad Nacional Autónoma de México.

BEBBINGTON, Anthony, ed. 2013. Industrias extractivas. Conflictos sociales y dinámicas institucionales en la Región Andina. Lima: IEP, CEPES, GPC.

---. 2007. Minería, movimientos sociales y respuestas campesinas. Una ecología política de transformaciones territoriales. Lima: IEP, CEPES, GPC.

BERRIOS, Ruben, Andrae Marak \& Scott Morgenstern. 2011. “Explaining Hydrocarbon Nationalization in Latin America: Economics and political ideology". Review of International Political Economy 18 (5): 1-25. [http://www.tandfonline.com/doi/pdf/10.1080/09692290.2010.493733] página descargada el 25 de agosto de 2014.

\footnotetext{
75 "La reforma Agraria en Bolivia, por Lucio Mendieta y Núñez. Antecedentes, Fundamentaciones y Metas". El Universal, México, 7 de abril de 1954; "Bolivia, al igual que México, reparte los latifundios a los campesinos", Excelsior. México, 4 de marzo de 1957.

${ }^{76}$ Biblioteca Lerdo de Tejada, AEH, Sección Bolivia, 1953.

${ }^{77}$ Veáse Ministerio de Agricultura, Ganadería y Riegos. Dirección Riegos. "Inauguración oficial y denominación de la Presa México". Cochabamba, Bolivia, 1953. En: AHSRE, 11418.
} 
BUCHELI, Marcelo. 2010. "Major Trends in the Historiography of the Latin American Oil Industry". Business History Review 84 (Special Issue 02): 339-62.

CARRIZO, Silvina Cecilia y Didier Ramousse. 2010. "Dinámicas energéticas e integración regional en el noroeste argentino y el sur boliviano". Revista de Geografía Norte Grande 45 (mayo): 51-62.

FRUS (Foreign Reports of the United States). 1938. "Informal Assistance to the Standard Oil Company of New Jersey in Connection with the Confiscation of its Properties in Bolivia". Vol. V. Washington: Duggan, Memorandum, March 16, 1938.

GALLEGO, Ferrán. 1992. Ejército, nacionalismo y reformismo en América Latina. La gestión de Germán Busch en Bolivia. Barcelona: PPU.

---. 1991. Los orígenes del reformismo militar en América Latina. La gestión de David Toro en Bolivia. Barcelona: PPU.

GAVALDÀ PALACÍN, Marc. 2005. "Los conflictos ambientales del gas boliviano". Iconos. Revista de Ciencias Sociales 21 (enero): 57-66.

---. 2005. "Etnocidio petrolero en Bolivia". Theomai 12.

GIRAUDO, Laura. 2010. “De la ciudad 'mestiza' al campo 'indígena': internados indígenas en el México posrevolucionario y en Bolivia". Anuario de Estudios Americanos 67/2 (julio-diciembre): 519-547.

GOJMAN de BACKAL, Alicia. 1988. La expropiación petrolera vista por la prensa mexicana, norteamericana e inglesa (1936-1940). México: Petróleos Mexicanos.

GUACHALLA, Luis Fernando. 1940. Defraudación petrolera en Bolivia. Nueva York: s/e.

GUDYNAS, Eduardo. 2007. "La diplomacia de la energía y el cruce de caminos en la integración suramericana". Programa de las Américas Observatorio Hemisférico. Washington DC: Center for International Policy.

HERRERA LEÓN, Fabián. 2009. La política mexicana en la Sociedad de Naciones ante la Guerra del Chaco y el conflicto de Leticia, 1932-1935. México: Secretaría de Relaciones Exteriores.

HOLLAND, Emmet James. 1967. "A Historical Survey of Bolivian Foreign Relations, 1935-1946". Tesis doctoral. School of International Service of the American University of Washington.

HUESCA, Robert. "The Mexican Oil Expropriation and the Ensuing Propaganda War". Texas Papers on Latin America, Pre-publication working paper of the Institute of Latin American Studies, University of Texas at Austin. 88-104. 
[http://lanic.utexas.edu/project/etext/llilas/tpla/8804.pdf] página descargada el 25 de agosto de 2014.

KIDDLE, Amelia. 2010. "La Política del Buen Amigo: Mexican-Latin American Relations during the presidency of Lázaro Cárdenas, 1934-1940". Tesis doctoral. Universidad de Arizona.

---. y María Cecilia Zuleta. 2013. La expropiación petrolera mexicana en la prensa de Latinoamérica. Antología documental. México: Archivo Histórico PEMEX.

KLEIN, Herbert. 1964. "American oil companies in Latin America: The Bolivian experience". Inter-American Economic Affairs 18 (2): 46-72.

KNUDSON, Jerry. 1986. Bolivia: Press and Revolution, 1932-1964. Boston: University Press of America.

LANGER, Erick. 1999. “Una mirada desde afuera. Una visión histórica de Bolivia en el siglo XX”. Bolivia en el siglo XX. La formación de la Bolivia contemporánea. La Paz: Harvard Club de Bolivia. 67-88.

LORA, Guillermo. 1967. Historia del movimiento obrero boliviano. Tomo IV (19331949). La Paz, Cochabamba: Editorial Los Amigos del Libro.

MAROF, Tristan (Gustavo Navarro). 1934. México de frente y de perfil. Buenos Aires: Editorial Claridad. Colección Ciencias Sociales.

MARVÁN LABORDE, Ignacio, coord. 2010. La Revolución mexicana, 1908-1932. México: FCE, CIDE, INHERM, CONACULTA.

MAURER, Noel. 2013. The Empire Trap. The Rise and Fall of U.S. Intervention to Protect American Property Overseas, 1893-2013. Princeton: Princeton University Press.

MEYER, Lorenzo. 2014. “Agenda ciudadana. El petróleo y la batalla por mantenerlo mexicano". El Siglo de Torreón (La Laguna) 14-marzo-2013. [http://www.elsiglodetorreon.com.mx/noticia/849378.html?full=true] página descargada el 25 de agosto de 2014.

---. 2009. Las raíces del nacionalismo petrolero en México. México, D.F.: Océano.

ORIHUELA, José Carlos y Rosemary Thorp. 2013. “La economía política del manejo de las industrias extractivas en Bolivia, Ecuador y Perú". Bebbington, Anthony, ed. Industrias extractivas. Conflicto social y dinámicas institucionales en la región andina. Lima: IEP, CEPES, GPC. 59-86.

OSORIO ROMERO, Sergio Benito. 2006. "El gas natural licuado: un factor de integración continental”. Rousseau, Isabelle, comp. ¿Hacia la integración de los mercados petroleros en América? México: Colegio de México. 131-73. 
PALACIOS, Guillermo. 2011. Historia de las relaciones internacionales de México, 1821-2010. Vol. 4. América del Sur. Mercedes de Vega, coord. México, DF: Secretaría de Relaciones Exteriores, Dirección General del Acervo Histórico Diplomático.

PÉREZ MONFORT, Ricardo. 2011. “La expresión popular y el 18 de marzo de 1938". 1938: La nacionalización de la industria petrolera en la historia de México. México: Petróleos Mexicanos. 273-89.

PHILIP, George. 2011. "Una perspectiva comparada dela expropiación". 1938: La nacionalización de la industria petrolera en la historia de México. México: Petróleos Mexicanos. 209-72.

RODMAN, Keneth A. 1988. Sanctity vs. Sovereignty. The United States and the Nationalization of Natural Resource Investments. New York: Columbia University Press.

ROUSSEAU, Isabelle. Comp. 2006. ¿Hacia la integración de los mercados petroleros en América? México: Colegio de México.

ROUT, Leslie. 1970. Politics of the Chaco Peace Conference. Austin and London: University of Texas Press, Institute of Latin American Studies.

ROY ARAMAYO, Carlos. 2008. "The Intellectual Origins of the Modern Bolivian Political System, 1918-1943". Tesis doctoral. Universidad de Yale.

RUIZ GUERRA, Rubén. 2007. Más allá de la diplomacia: relaciones de México con Bolivia, Ecuador y Perú, 1821-1994. México, DF: Secretaría de Relaciones Exteriores, Dirección General del Acervo Histórico Diplomático (Colección Latinoamericana).

SANJINÉS, Alfredo. 1932 [1930]. La reforma agraria en Bolivia. Segunda Edición. La Paz: Editorial Renacimiento.

SANTIAGO, Myrna. 2006. The Ecology Oil. Environment, Labor, and the Mexican Revolution, 1900-1938. New York: Cambridge University Press.

SCHULER, Friedrich E. 1998. México: Between Hitler and Roosevelt. Mexican Foreign Relations in the Age of Lázaro Cárdenas, 1934-1940. Albuquerque: University of New Mexico Press.

STANDARD Oil Company of Bolivia. 1939. Confiscation: a history of the oil industry in Bolivia. New York: Standard Oil.

UNITED STATES TARIFF COMMISSION. 1942. The Foreign Trade of Latin America: A Report on the Trade of Latin America with Special Reference to Trade with the United States under the Provisions of Title III, pt. II, seccion 332 of the Tarif Act of 1930. Report 146. Washington DC: U.S. Govt. Print Office. 
VALDIVIESO, José de y Carlos Salamanca. 1942. La Standard Oil en Bolivia:

caducidad de concesiones petrolíferas. Cochabamba: Universidad Autónoma de Cochabamba, Imprenta Universitaria, Publicaciones de la Facultad de Derecho y Ciencias Sociales.

ZULETA, María Cecilia. 2013. "Horizontes, negociaciones y disyuntivas en los tratos de YPFB con YPF, 1937-1945”. Revista de Gestión Pública II.1 (enero-julio): 107-143.

\section{Archivos y prensa consultada}

ABNB. Archivo y Biblioteca Nacionales de Bolivia (Bolivia).

AEH. Archivos Económicos Hemerográficos. Biblioteca Miguel Lerdo de Tejada (México).

AHSRE. Acervo Histórico Diplomático de la Secretaría de Relaciones Exteriores (México).

AHMREB. Archivo Histórico de la Cancillería. Ministerio de Relaciones Exteriores. Estado Plurinacional de Bolivia (Bolivia).

Archivo de la Cancillería (Bolivia).

Biblioteca Municipal y Hemeroteca de la Universidad Mayor de San Andrés (Bolivia).

Centro de Estudios de Historia de México CARSO-Fundación Carlos Slim (México).

\section{(c) $)$ EY}

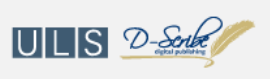

New articles in this journal are licensed under a Creative Commons Attribution 4.0 United States License.

This journal is published by the University Library System of the University of Pittsburgh as part of its D-Scribe Digital Publishing Program, and is cosponsored by the University of Pittsburgh Press. 